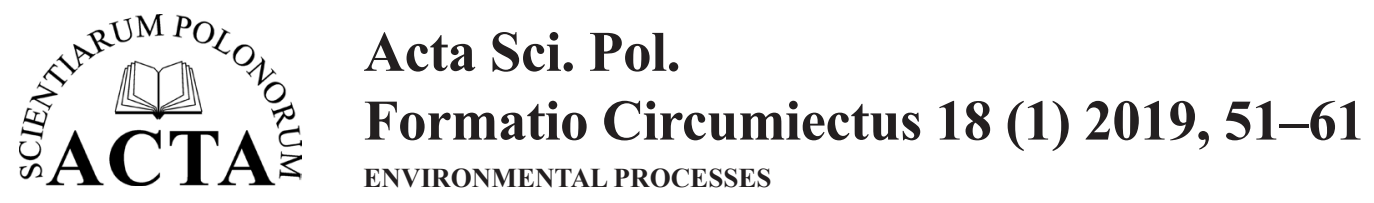

www.formatiocircumiectus.actapol.net/pl/

ISSN 1644-0765

DOI: http://dx.doi.org/10.15576/ASP.FC/2019.18.1.51

ORIGINAL PAPER

Accepted: 30.10 .2018

\title{
SELECTION OF THE OPTIMAL TYPE OF FISH PASS USING THE REMBRANDT METHOD
}

\author{
Mateusz Hämmerling \\ Department of Hydraulic and Sanitary Engineering, Poznań University of Life Sciences, Piątkowska 94 A, 60-649 Poznań
}

\begin{abstract}
Aim of the study

Aim of the paper was to use the Rembrandt multi-criteria decision support method to select the best type of fish pass for the analysed barrage, depending on the priorities adopted.

Material and methods

Hydraulic structures interrupt the continuity of morphological and biological watercourse, divide it into sections, which cannot be crossed by fish and other aquatic organisms. It is particularly disadvantageous, because motion up- and downstream is indispensable for them to live. For this reason fish passes are built on barrages to facilitate their migration. The article presents hydraulic calculations run for three types of fish passes. Also, a hierarchical tree was prepared in accordance with the Rembrandt method. This tree has been applied three times: for the owner's preferences, for aquatic organisms, and without imposing a second level of calculation.
\end{abstract}

\section{Results and conclusions}

Results of calculations using Rembrandt's multi-criteria decision support method indicated that according to the investor's priorities the best fish pass was slot pass, for aquatic organisms - bypass channel, and calculations which assumed equal values for second level factors also point to slot pass.

Keywords: fish pass, barrage, Rembrandt method

\section{INTRODUCTION}

The man utilizes rivers disturbing their natural processes. This includes changing conditions of vegetation growth and aquatic organisms, as well as limiting their movement. Interrupting rivers' courses is one of the biggest problems that restrict the number of migratory fish from the end of the 19th century. Passes structures are difficult to cross obstacles on fish journey according to stream direction (Ligięza, 2017). Whereas, for fish travelling upstream, hydrotechnical constructions that pose challenges.
There are various types of fish passes, which differ in their design, size, amount of water used, flow rates and other hydrodynamic parameters. Generally, one can distinguish technical, seminatural and non-standard fish passes.

Among the technical: chamber, slot, Denil and eel passes can be distinguished. Chamber type fish ladders are one of the oldest structures enabling fish to travel up and down the stream. They are made of chambers, divided with concrete and wooden walls, which have windows cut out at the bottom and in the upper part of a baffle. Riverbeds of chamber fish passes consist

凶e-mail: mhammer@up.poznan.pl 
of concrete and rocks. Baffles can be either already prefabricated or made out of wooden elements. Another type of fish passes is slot pass, a modified version of chamber pass. The element that allows aquatic organisms to pass between chambers has been changed. Instead of pass windows, a vertical slot runs across the entire height of a baffle (Jones and O'Connor, 2017). It necessary, when designing this type of fish pass, to have in mind that slots in a fish pass should not draw a straight line, so that water current does not lose its velocity. For this reason either alternate slot pattern is applied or they are being equipped with a hook (see: Fig. 1), which is supposed to reduce the velocity of water current and directing it in a curve (Lubieniecki, 2002).

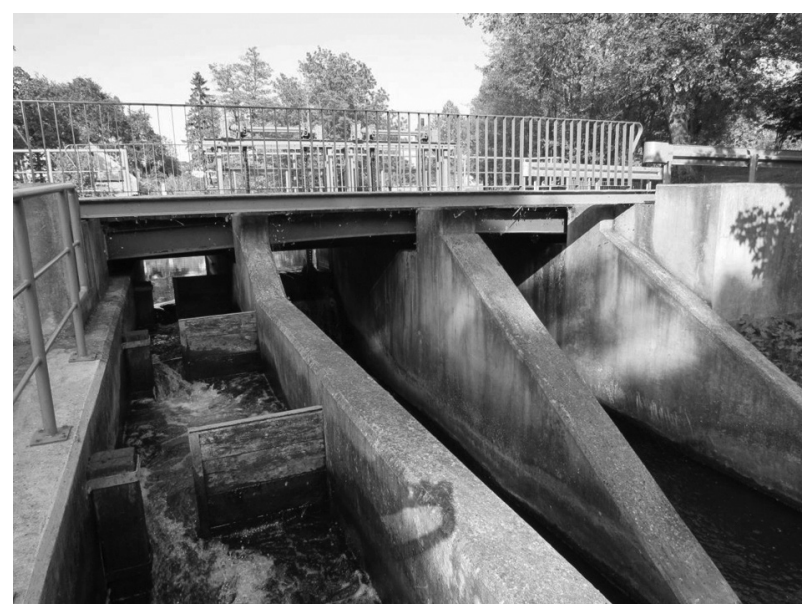

Fig. 1. Slot passes (Krajenka barrage on the Głomia river)

Apart from single-pass fish passes, one can also distinguish two-slotted constructions, which can be used if larger volumes of water are to pass through a fish passes. Another example of technical construction is the Denil fish pass, shaped like a gutter, which comprises so-called ribs that reduce water flow velocity. The advantage of Denil passes is that they can have a large drop and thus occupy very little space. Eel passes can be closed in a riverbed (filled with branches) or opened from top to bottom. The second type fulfils its task better due to lower probability of silting a fish pass (Lubieniecki, 2002).

The second of the basic fish passes types is seminatural, which includes: bypass channels (see: Fig. 2),

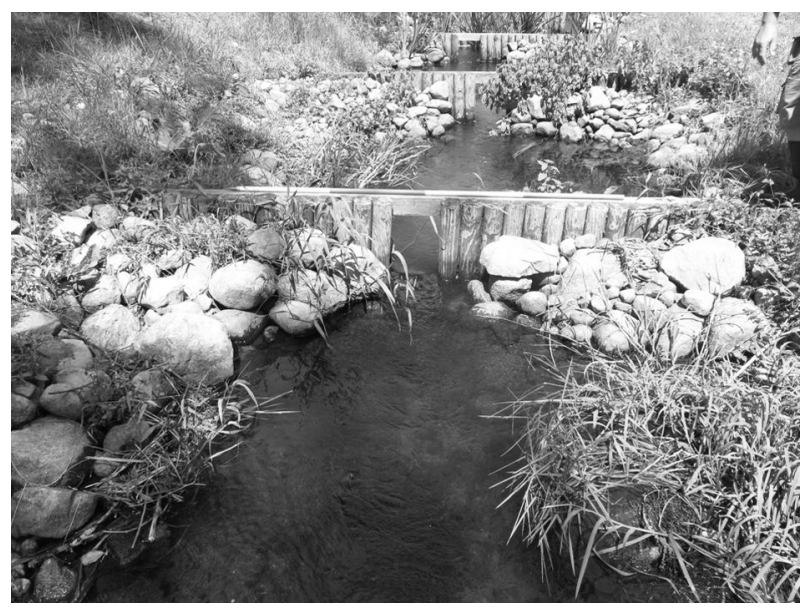

Fig. 2. Seminatural fish pass (Skórka barrage on the Głomia river)

pool passes, ramps or ladders at a barrage, riffles and abrupt overflows. Bypass channel takes shape of a natural watercourse, which with thresholds and stones built in.

Pool passes consist of meshes connected with small channels with water flowing through them in small overflows. Mesh arrangement depends on terrain shape (Mokwa, 2007). Ramps or rampings at a barrage are built into a clearance of barrage and can be located in the axis or near the wall of an overflow device (Mokwa, 2010). The slope of the bottom of a ramp should be as smooth as possible and be made of stones or stone thresholds that reduce water flow velocity (WWF, 2016). Ramps and bottom ramps are devices that allow aquatic organisms to pass through an obstacle. Solving the problem of migration of aquatic organisms in this way also enables replacing a mobile weir. Examples of atypical fish passes are fish locks, fish lifts and car transport. Possibilities of fish transport using modular segments placed on cars are presented by Chomek and Kasperowicz (2013). Fish locks work similarly to locks dedicated to ships, i.e. they have a large chamber with lower and upper regulation of inflow and outflow (Hämmerling and Franczak, 2012). Fish lifts are used especially for dams with a high level of damming, where a conventional fish passes would occupy too much area.

In order to select an optimal type of fish pass, an analysis of many ichtiological, technical and economic factors is required. Support methods facilitate a deci- 
sion process. They provide an easy to understand and flexible model for a wide range of problems, introducing also an assessment scale for non-measurable elements and a method for prioritizing. Therefore, in this paper, the Rembrandt multi-criteria decision method was used to assess the most favourable type of device facilitating fish migration, which has not been widely used in water engineering until now.

\section{METHODOLOGY}

Calculations were made according to the Rembrandt method, which is basic for analytical hierarchy. This method is a very useful tool for decision-making, which has to take into account multiple factors and parameters, such as e.g. costs of requirements related to fish (biological parameters), hydraulic requirements, investor requirements and construction possibilities. Applying multi-criteria analysis provides the best solution based on the significance of individual priorities.

The Rembrandt method was created in response to objections raised against a basic method of analytical hierarchy, AHP, concerning: scale of assessments and a method of obtaining synthetic evaluation of variants. In the discussed method, the Saat scale has been replaced by a logarithmic scale, and its hierarchical tree consists of three levels. The highest on the tree is the objective, below are the factors (evaluation criteria) and the lowest is the solution (Trzaskalik, 2014). The least square logarithm method is used for determining scale vectors, and the variants are evaluated by using a rule based on a geometric mean (Lootsma, 1992). This method either delivers a ranking of objects (decision variants) or allows grouping classes into so-called preference groups (Pośpiech and Mastalerz-Kodzis, 2015).

The basic parameters necessary for designing passes are biological and hydraulic.

Biological parameters are associated with fish migration, which is caused by various factors, primarily achieving subsequent life stages, as well as beating the water current. In the case of bi-environmental fish, migration is the basis for preservation of a population. The period of fish migration depends on biology and life span of species, and seasonal changes. For this reason, in the adopted scenarios it was assumed that a fish pass is to operate all year round.
When designing fish passes, it is necessary to meet basic conditions. The principles of proper design of fish passes suggest that a fish pass should be efficient at all water levels enabling fish migration (Mokwa and Tarnawski, 2008). Ensuring an adequate water velocity in the river near the water outlet from a fish pass provides water current that entices fish. In addition, such parameters of fish pass as width of the slots, dimensions of the chambers, which depend on the species of fish migrating through a given river, should be taken under consideration. Also, it is important to ensure that there is an adequate difference of water levels between chambers.

A few scenarios for fish passes have been selected. The first is a slot pass, the second - seminatural pass, the third - fish ramp. The analysis was run for the barrage located in Wielkopolska, consisting of power plant, weir and fish pass. Penczak et al. (2008) found that fish in the studied river are roach, perch and rheophylic fish such as, for example, gudgeon, grayling, brown trout and others. The height of water damming at the analysed barrage is $H_{p}=2.92 \mathrm{~m}$.

On the grounds of the assumptions presented above hydraulic calculations of different ideas for fish passes were made. The hydraulic parameters necessary to determine when designing a fish pass include: maximum velocity, water flow rate, average differences of water levels between baffles, dissipation of water energy in a chamber. The results obtained with the basic formulas for hydraulic calculations of water flow parameters were compared with the admissible values. According to Mokwa and Tarnawski (2008), the maximum acceptable water velocity in a fish pass for rheophilic fish is $1.5 \mathrm{~m} \cdot \mathrm{s}^{-1}$, and according to WWF (2016) $2.0 \mathrm{~m} \cdot \mathrm{s}^{-1}$. The dissipation of turbulence energy in a chamber should be smaller than $150 \mathrm{~W} \cdot \mathrm{m}^{-3}$. The following formulas are used to determine the basic hydrodynamic parameters in a slot pass.

Maximum water velocity in a slot (WWF, 2016):

$$
v_{\max }=\sqrt{2 \cdot g \cdot \Delta h}
$$

$v_{\max }-$ maximum velocity, $\mathrm{m} \cdot \mathrm{s}^{-1}$

$g \quad$ - gravitational acceleration, $\mathrm{m} \cdot \mathrm{s}^{-2}$.

$\Delta h$ - difference in water levels between chambers, $\mathrm{m}$ 
Water flow rate in a slot (WWF, 2016):

$$
Q=\frac{2}{3} \cdot \mu_{r} \cdot s \cdot \sqrt{2 \cdot g \cdot h_{0}^{\frac{2}{3}}}
$$

$Q$ - flow rate, $\mathrm{m}^{3} \cdot \mathrm{s}^{-1}$

$\mu_{r}$ - flow coefficient, -

$s$ - slot width, $\mathrm{m}$

$g$ - gravitational acceleration, $\mathrm{m} \cdot \mathrm{s}^{-2}$.

$h_{o}$ - water depth at the beginning of a chamber, $\mathrm{m}$

Volumetric energy dissipation (WWF, 2016):

$$
E=\frac{\rho \cdot g \cdot \Delta h \cdot Q}{b \cdot h_{m} \cdot(l-d)}
$$

$E$ - volumetric energy dissipation, $\mathrm{W} \cdot \mathrm{m}^{-3}$

$\rho$ - water volume density, $\mathrm{kg} \cdot \mathrm{m}^{-3},\left(1000 \mathrm{~kg} \cdot \mathrm{m}^{-3}\right)$

$\Delta h$ - difference in water levels between fish pass chambers, $m$

$b$ - chamber width, $\mathrm{m}$

$h_{m}-$ average water depth in a chamber, $\mathrm{m}$

$l^{m}$ - chamber length, $\mathrm{m}$

$d$ - baffle length, $\mathrm{m}$

Calculations of hydraulic parameters of a fish ramp and a bypass channel were made with the formulas 4 6 described in WWF (2016). 2016):

Determination of maximum drag coefficient (WWF,

$$
\hat{\kappa}_{c} \stackrel{\hat{\kappa}_{s}}{=} \frac{\kappa_{0} \cdot\left(1-\varepsilon_{0}\right)}{1-\varepsilon_{v}}
$$

$\lambda_{c}-$ total resistance coefficient,

$\lambda_{s}-$ resistance coefficient resulting from the presence of stones and rocks in a riverbed,

$\lambda_{o}-$ resistance coefficient resulting from the roughness of river bed,

$\varepsilon_{v}-$ volumetric throttling coefficient,

$\varepsilon_{o}$ - surface throttling coefficient,
Drag coefficients resulting from the presence of stones and rocks in a riverbed and roughness of riverbed were calculated with the formulas described in WWF (2016), using parameters of stones and riverbeds. Volumetric throttling coefficient is a quotient of volume of submerged stones to total volume of stones, and surface throttling coefficient is the surface of stones ratio to the total surface of stones (WWF, 2016).

Average velocity (WWF, 2016):

$$
V_{m}=\sqrt{\frac{8 \cdot g \cdot R_{h} \cdot I}{\hat{\Lambda}_{c}}}
$$

$v_{m} \quad$ - average flow velocity, $\mathrm{m} \cdot \mathrm{s}^{-1}$

$g \quad$ - gravitational acceleration, $\mathrm{m} \cdot \mathrm{s}^{-2}$.

$R_{h} \quad$ - hydraulic radius, $\mathrm{m}$

$i \quad$ - hydraulic slope, -

$\lambda_{c}-$ total resistance coefficient,

Maximum velocity (WWF, 2016):

$$
V_{\max }=\frac{V_{m}}{1-\frac{A_{s}}{A}}
$$

$v_{\max }-$ maximum flow velocity, $\mathrm{m} \cdot \mathrm{s}^{-1}$

$v_{m}$ - average flow velocity, $\mathrm{m} \cdot \mathrm{s}^{-1}$

$A_{s}$ - wet area of all rocks, $\mathrm{m}^{2}$

$A$ - cross-section area, $\mathrm{m}^{2}$

Fig. 3 presents the hierarchical tree used for selecting the best fish pass solution for the analysed barrage.

Values for individual factors were determined on the basis of hydraulic calculations, expert knowledge (the so-called expert method) and cost estimates for particular types of fish passes. Costs were estimated as average values per running metre of a particular type of fish pass. The paper compares pairs of factors on the backdrop of selecting the best fish passes for the investor's priorities and for aquatic organisms. 


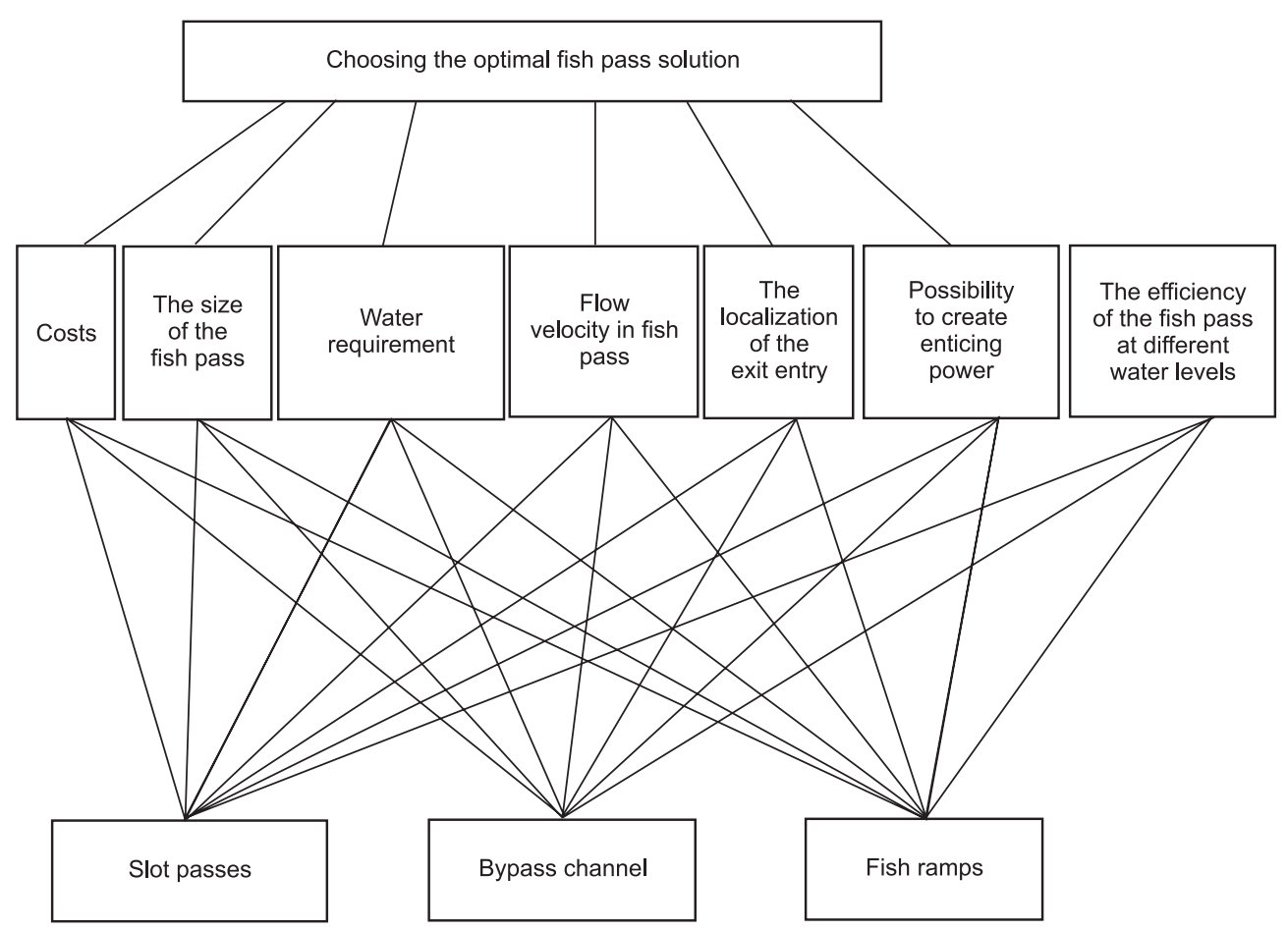

Fig. 3. The hierarchical tree for selection of fish pass according to the Rembrandt method

\section{RESULT ANALYSIS}

Parameters for each type of fish pass were calculated on the basis of the presented methodology. Fig. 4 shows a sketch of the barrage with an arrangement of fish passes.

The chambers of the slot pass had the following dimensions: chamber length $2.00 \mathrm{~m}$, chamber width $1.30 \mathrm{~m}$, slot width $0.18 \mathrm{~m}$, hook size $0.16 \mathrm{~m}$, number of chambers: 25. Hydraulic parameters were also determined - respectively: water flow velocity $v_{m}=1.5 \mathrm{~m} \cdot \mathrm{s}^{-1}$, difference in water levels between chambers $\Delta h=0.11 \mathrm{~m}$, flow rate, $0,16 \mathrm{~m}^{3} \cdot \mathrm{s}^{-1}$, energy dissipation $87 \mathrm{~W} \cdot \mathrm{m}^{-3}$. The designed slot pass was $52.5 \mathrm{~m}$ long and its bed drop was $5.5 \%$. According to the design of slot pass, single large stones were inserted into the riverbed with loose stones placed irregularly between them. This way a fish pass enables migration of small fish species.

The bypass channel was designed as a trapezoidal channel with a width of $2 \mathrm{~m}$, a slope of $1: 2$ and a water depth of $0.7 \mathrm{~m}$. The channel with a drop of $2 \%$ was
$146 \mathrm{~m}$ long and was filled with rocks with a diameter of $0.6 \mathrm{~m}$ and a gauge of $1.2 \mathrm{~m}$. Hydraulic parameters calculated with empirical formulas were as follows: maximum velocity $V_{\max }=0.88 \mathrm{~m} \cdot \mathrm{s}^{-1}$, average velocity $V_{m}=0.73 \mathrm{~m} \cdot \mathrm{s}^{-1}$, necessary amount of water at the filling of $0.7 \mathrm{~m}$ was $Q=1.73 \mathrm{~m}^{3} \cdot \mathrm{s}^{-1}$.

The fish ramp was designed as an integrated part of the weir and was characterized by the following dimensions: width of the fish ramp was $2.45 \mathrm{~m}$ and it was due to span width of the existing weir. Length of the fish ramp was $78 \mathrm{~m}$, bed drop - 0.05, diameter of a single rock was $0.3 \mathrm{~m}$, and their number in a cross-section was 3 . Hydraulic parameters were: average velocity $V_{m}=1.46 \mathrm{~m} \cdot \mathrm{s}^{-1}$, maximum velocity $V_{\max }=1.88 \mathrm{~m} \cdot \mathrm{s}^{-1}$, and amount of water needed for the fish pass to operate $Q=1.79 \mathrm{~m}^{3} \cdot \mathrm{s}^{-1}$.

Based on calculated parameters of assumed fish pass types, an analysis was perforemd with the Rembrandt multi-criteria decision-making method. Fig. 5 shows values of solution vectors for individual factors depending on the priorities of the owner or aquatic organisms. 


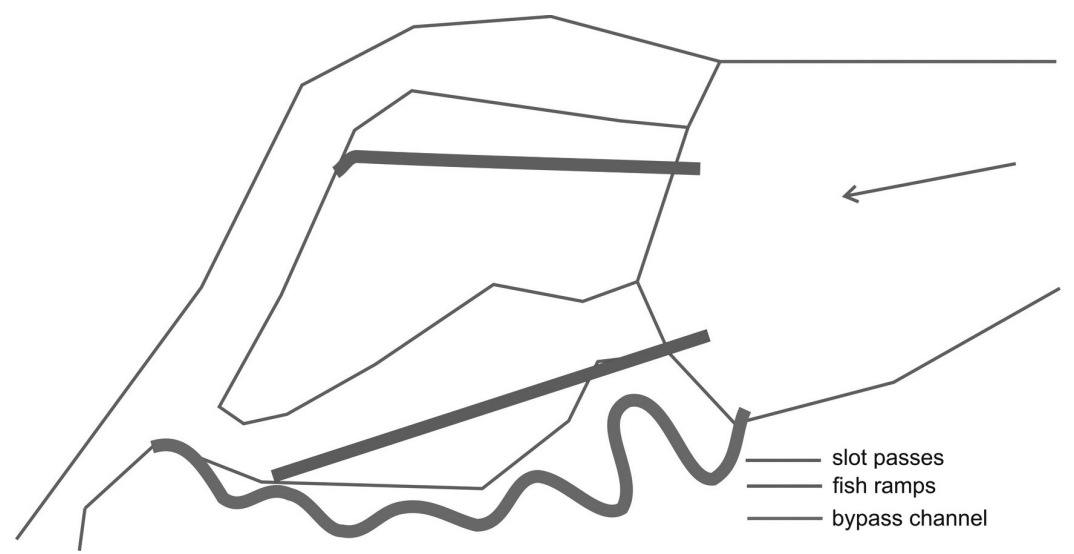

Fig. 4. Sketch of the barrage with individual solutions of fish passes

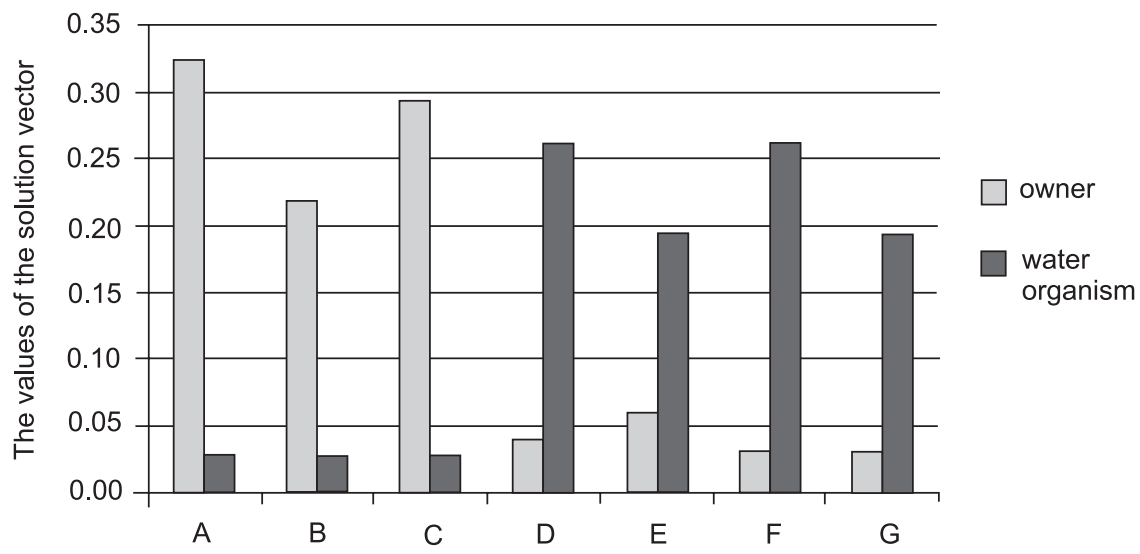

Fig. 5. The global vector values of individual factors depending on the priority, A - costs, B - size of a fish pass, C - water requirement, D - flow velocity in a fish pass, E - localisation of exit entry, F - possibility of generating enticing current, $\mathrm{G}$ - efficiency of a fish pass at different water levels

For the owner's priority, the largest value of the solution vector was obtained by the construction costs factor (0.33), then the water demand (0.29), the lowest value of the vector came out for the possibility of generating enticing current (0.03). Whereas, for the priority of aquatic organisms the most important factors were water flow velocity in a fish pass $(0.26)$ and the possibility of decreasing enticing current (0.26), and the least significant were size, construction costs and water demand. An analysis of results displayed a division of significance of individual factors by priority.
In further analysis, individual types of fish passes were compared against complex factors. Seven matrices have been solved twice. On their basis local vectors were calculated, which then were converted into global vectors using the values from second level matrix. Fig. 6. presents results of calculations of global vectors for the level associated with scenarios of solutions to the assumed problem.

According to the owner's priority, the most favourable solution (0.72) is to build a chamber pass, second came a bypass channel $(0.16)$. For the priority of aquatic organisms, the most favourable (0.42) 
a)

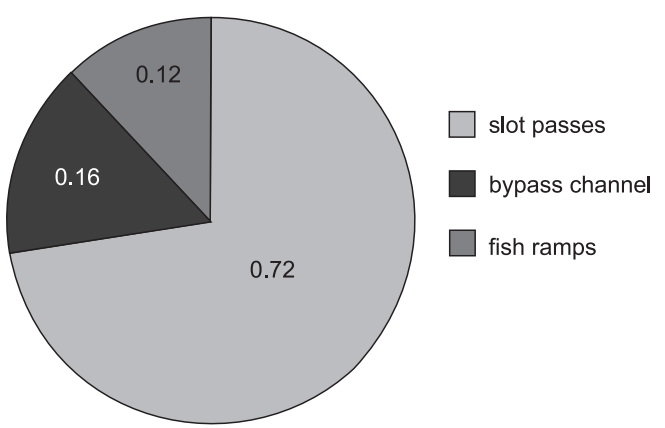

b)

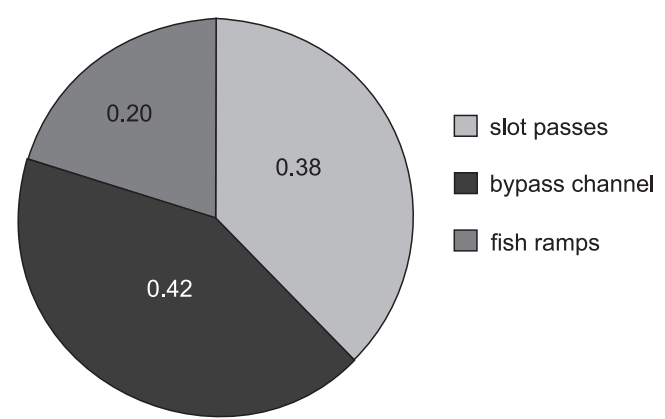

Fig. 6. The results of calculations of global vectors for individual solutions depending on the assumed priorities. a) owner b) water organisms

is bypass channel, followed by a slot pass (0.38). An analysis of results indicates that for the tested barrage according to the owner's priority, it would be the best to build a slot pass, whereas for aquatic organisms bypass channel.

\section{DISCUSSION}

For a slot pass, hydraulic parameters were compared with admissible values. The difference in water levels between chambers is $0.11 \mathrm{~m}$. less than the limit value of $0.15 \mathrm{~m}$, the energy dissipation is $87 \mathrm{~W} \cdot \mathrm{m}^{-3}$ and is smaller than the limit value of $150 \mathrm{~W} \cdot \mathrm{m}^{-3}$. An advantage of slot pass is low sensitivity to changes in water levels for its proper functioning (Larinier, 2002).

The hydraulic parameters calculated for a bypass channel are highly favourable for fish due to low velocity comparing to a slot pass, which is smaller than $0.7 \mathrm{~m} \cdot \mathrm{s}^{-1}$ and totals $V_{m}=0.73 \mathrm{~m} \cdot \mathrm{s}^{-1}$; and half as small bed drop compared to a slop pass. Flow rate of a bypass channel has increased in comparison to a slop pass from $Q=0.16 \mathrm{~m}^{3} \cdot \mathrm{s}^{-1}$ to $Q=1.73 \mathrm{~m}^{3} \cdot \mathrm{s}^{1}$, which is unfavourable for a user due to water losses, especially during low flows. According to WWF (2016) and Gustafsson et al. (2013), rheophilic fish (living in waters with strong currents) can also use bypass channels as habitats. Construction of this type of fish pass is independent of a barrage, which is beneficial in case of supplementing a barrage with a fish pass, but due to its size it occupies a large area.

For a fish ramp, average velocities were similar to those for a slot pass (about $1.46 \mathrm{~m} \cdot \mathrm{s}^{-1}$ ), i.e. with- in acceptable rates. Flow rate was similar to that for a bypass channel. The drop of a riverbed was larger than in a bypass channel, which led to increased average velocity. The ramp was more than a half shorter than the bypass channel for fish. Comparing basic parameters of fish ramp and other types of discussed fish passes, it can be concluded that it is less beneficial for both the owner and aquatic organisms. According to Tymiński et al. (2016), construction of fish ramps is a good solution in case of replacing fixed thresholds and weirs and for species of fish with good swimming abilities.

Williams et al. (2012) argue that hydraulic and biological research requires large financial outlays, especially when there is no information on behaviour of individual fish species inhabiting a given river. In addition, lack of sufficient hydraulic and biological knowledge means that very often a lot of attempts have to be made to develop a proper solution for migration of aquatic organisms. When choosing the best type, a question always arises as to which parameters of fish passes are the most important and which can be omitted. It all depends on the needs of a given group. It is difficult to select the best solution when having several types of passes at choice and analysing multiple parameters. O'hanley and Tomberlin (2005) also presented an innovative approach to decision making in regard to reducing barriers to fish migration using programming in the state of Washington.

A detailed analysis of 7 factors from second level for comparing the assumed types of fish passes (level III) were presented in Fig. 7. 


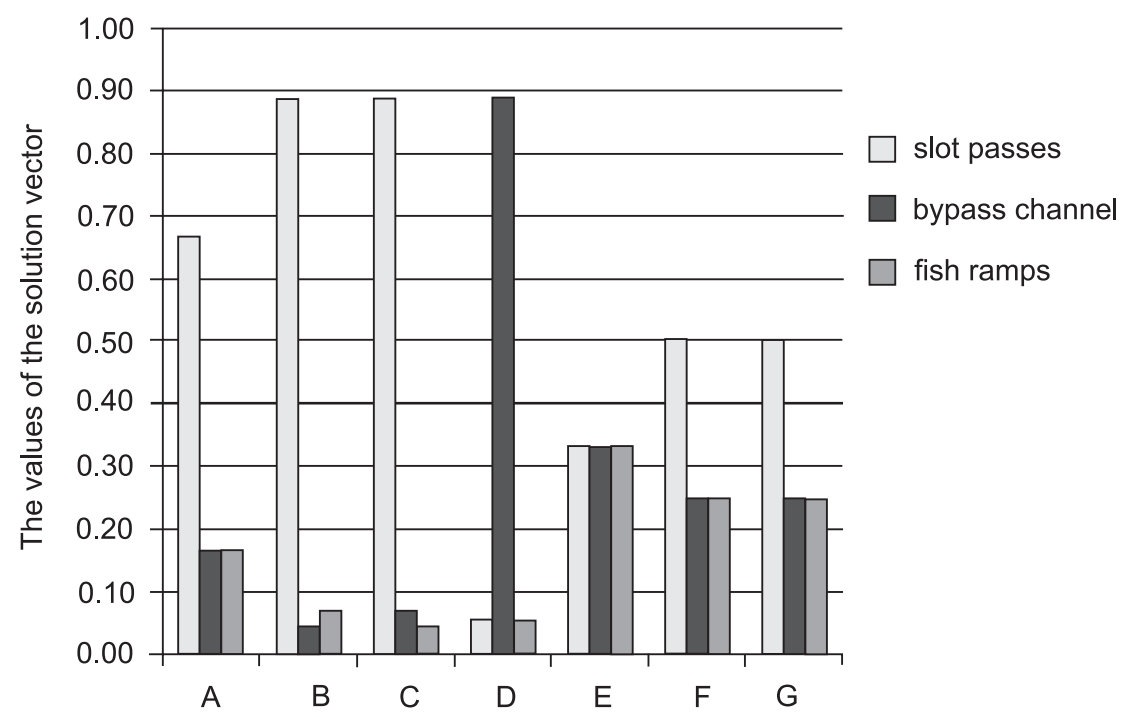

Fig. 7. The local vector values for third matrix level, A - costs, $B$ - size of a fish pass, $\mathrm{C}$ - water requirement, $\mathrm{D}$ - flow velocity in a fish pass, $\mathrm{E}$ - the localization of exit entry, $\mathrm{F}$ - possibility to generating enticing current, $\mathrm{G}$ - the efficiency of a fish pass at different water levels

Fig. 7 shows solutions of local vectors for individual third level matrices. On their basis the best solution for individual factors can be indicated. Construction costs were determined by costs of other fish passes of this type. According to calculations, the cheapest proved to be a slot pass. The size of a fish pass was mainly understood as dimensions of a fish pass, which is why the best solution was a slot pass and the worst - a bypass channel. The values of factors related to water demand and water flow velocities in a fish pass were determined in hydraulic calculations. Flow rates and velocities depend on water filling in a fish pass (Pena et al., 2018).

According to Clay (2017), an entrance to a fish pass may be its most important element. An entrance to a fish pass can be in two ways in relation to the course of a river: parallel or perpendicular. Adam and Bosse (2014) and other researchers argue that more beneficial is an entrance parallel to water current flowing from a weir, while Dodd et al. (2014) reckon that a perpendicular entrance guarantees very high efficiency (86\%). Bunt (2001) claims that fish pass entrance should be located as close as possible to a dam or weir, but in such a way that an outflow from a passes structure does not disturb functioning of a fish pass.
The possibility of generating an enticing current does not only involve the volume of water flowing through a given fish pass (Zgrabczyński, 2007). Often, the strongest enticing current belongs to water flowing out from power plant turbines. Therefore, it is recommended to locate there an inlet to a fish pass, preferably at the edges of turbulence field of an outflow (Mokwa and Tarnawski, 2008). Haro et al. (2004) argue that swimming abilities depend on species characteristics of aquatic organisms. Therefore, it is also necessary to take under consideration this aspect, when designing a water outlet from a fish pass. With an assumption of continuous operation of a hydroelectric power plant, the most preferable solution proved to be a slot pass. Bunt et al. (2012) conducted efficiency tests of a seminatural and technical fish pass, and on this basis they found that efficiency of seminatural fish passes is lower.

Applying the solutions of the 7 matrices presented above, the results were converted into global vectors and solutions for the preferences of the owner and aquatic organisms were obtained. Due to the fact that it was not possible to choose one type of fish pass, which would fit simultaneously for both preferences of the owner and aquatic organisms, calculations 
were prepared in which preferences of all factors from the second level of hierarchical tree were equal (see: Fig. 8), which allowed selecting the best type of fish passes.

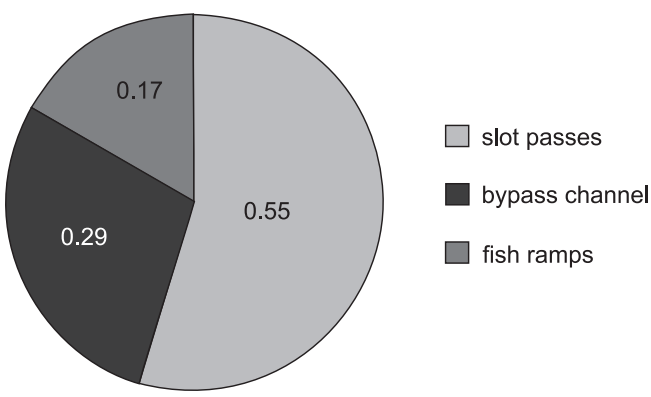

Fig. 8. Results of global vector calculations for individual solutions with equal distribution of priorities for the second level of hierarchical tree

An analysis of solution matrices of dependencies between particular types of fish passes has proven that the best one is a slot pass. Several factors affected this choice. This type of fish pass consumes much less water than seminatural pass. It also requires little space, usually has a compact design and works better at different water levels.

\section{SUMMARY}

The paper presents a study on selection of the optimal type of fish passes using the Rembrandt decision-making method on an example of a barrage in Wielkopolska. Hydraulic calculations were run for three assumed types of fish passes: slot pass, bypass channel and fish ramp. The results together with other data describing the designed fish passes were used for calculations by the multi-criteria decision-making method.

Based on the analyses, it can be concluded that choosing the right type of fish pass involves searching for optimal compromise between different needs. For the owner of the barrage, a fish pass is another component in the cost estimate for construction of the barrage, and an element that causes water outflow to a lower station - water that could be used for other purposes, e.g. for production of electricity. Taking into account the needs of aquatic organisms, it is important to remember that maximum water velocities flowing in a fish pass cannot be exceeded.

The paper includes calculations with the Rembrandt method using various preferences. According to the owner's priorities, the best is a slot pass and according to the priorities of aquatic organisms - bypass channel. Equalizing the significance of factors for the second level of hierarchical tree allowed finding the best type of fish pass, i.e. slot pass.

Calculations using the multi-criteria decision-making method allow determining the most favourable type of object for a given barrage, depending on adopted priorities. This method can be used as an aid in designing various types of hydrotechnical objects.

\section{REFERENCES}

Adam, B., Bosse, R. (2014). Fish Passes e Design, Dimensions and Monitoring. DWARegelwerk. Merkblatt DWA-M509

Bunt, C. M. (2001). Fishway entrance modifications enhance fish attraction. Fisheries Management and Ecology, 8(2), 95-105.

Bunt, C. M., Castro-Santos, T., \& Haro, A. (2012). Performance of fish passage structures at upstream barriers to migration. River Research and Applications, 28(4), $457-478$.

Chomka, G., Kasperowicz, M. (2013). Techniczne aspekty transportu żywych ryb słodkowodnych. Autobusy: technika, eksploatacja, systemy transportowe, 14, 69-72.

Clay, C. H. (2017). Design of fishways and other fish facilities. CRC Press.

Dodd, J. R., Cowx, I. G., Bolland, J. D. (2017). Efficiency of a nature-like bypass channel for restoring longitudinal connectivity for a river-resident population of brown trout. Journal of environmental management, 204, 318-326.

Gustafsson, S., Ósterling, M., Skurdal, J., Schneider, L. D., Calles, O. (2013). Macroinvertebrate colonization of a nature-like fishway: the effects of adding habitat heterogeneity. Ecological engineering, 61, 345-353.

Haro, A., Castro-Santos, T., Noreika, J., Odeh, M. (2004). Swimming performance of upstream migrant fishes in open-channel flow: a new approach to predicting passage through velocity barriers. Canadian Journal of Fisheries and Aquatic Sciences, 61(9), 1590-1601.

Hämmerling, M., Franczak, D. (2012). Scenariusze rozwoju i badania hydrauliczne przepławek dla ryb. 
Jones, M.J. and O'Connor, J.P. (2017). Monitoring the performance of fishways and fish passage works. Arthur Rylah Institute for Environmental Research. Technical Report Series No. 257. Department of Environment, Land, Water and Planning, Heidelberg, Victoria.

Larinier, M. (2002). Fish passage through culverts, rock weirs and estuarine obstructions. Bulletin Francais de la Peche et de la Pisciculture, (364), 119-134

Ligięza, J., Adamczyk, M., Prus, P., Wiśniewolski, W. (2017). Monitoring ryglowej przepławki dla ryb i optymalizacja jej funkcjonowania, Roczniki Naukowe Polskiego Związku Wędkarskiego, 30, 95-120.

Lootsma F.A. (1992). The REMBRANDT system for multi-criteria decision analysis via pairwise compańsons or direct rating, Report 92-05, Faculty of Technical Mathematics and Informatics, Delft University of Technology, Delft.

Lubieniecki B. (2002). Przepławki i drożność rzek, Wydawnictwo Instytu Rybactwa Śródlądowego, Olsztyn

Mokwa, M. (2007). Przepławki dla ryb na stopniach regulacyjnych potoków górskich. Infrastruktura i Ekologia Terenów Wiejskich, (4/2).

Mokwa, M., Tamawski, K. (2008). Ocena hydrauliczna działania przepławki dla ryb przystopniu wodnym Brzeg Dolny. Infrastruktura i Ekologia Terenów Wiejskich, (07).

Mokwa, M. (2010). Obliczenia hydrauliczne przepławek dla ryb. Acta Scientiarum Polonorum, Wydawnictwo Uniwersytetu Rolniczego w Krakowie, 43-58.

O'hanley, J. R., Tomberlin, D. (2005). Optimizing the removal of small fish passage barriers. Environmental Modeling \& Assessment, 10(2), 85-98.
Pena, L., Puertas, J., Bermúdez, M., Cea, L., Peña, E. (2018). Conversion of Vertical Slot Fishways to Deep Slot Fishways to Maintain Operation during Low Flows: Implications for Hydrodynamics. Sustainability, 10(7), 2406.

Penczak, T., Kruk, A., Marszał, L., Zięba, G., Galicka, W., Tszydel, M., Tybulczuk, Sz., Pietraszewski, D. (2008). Monitoring ichtiofauny systemu rzeki Gwdy: trzecia dekada badań. Rocz. Nauk. PZW, 21, 61-89.

Pośpiech, E., \& Mastalerz-Kodzis, A. (2015). Wybór metody wielokryterialnej do wspomagania decyzji inwestycyjnych. Zeszyty Naukowe. Organizacja í Zarządzanie/ Politechnika Śląska.

Trzaskalik, T. (2014). Wielokryterialne wspomaganie decyzji. Przegląd metod i zastosowań. Zeszyty Naukowe. Organizacja i Zarządzanie Politechnika Śląska.

FAO/DVWK/WWF.PL 2016. Przepławki dla ryb - projektowanie, wymiary i monitoring, Warszawa.

Tymiński, T., Mumot, J., Strojny, R., \& Karpowicz, D. (2016). Analysis of the potential of building ramps in hydrotechnical structures as a means of facilitating fish migration. Acta Scientiarum Polonorum, Formatio Circumiectus, 15(3), 151-162.

Williams, J. G., Armstrong, G., Katopodis, C., Larinier, M., \& Travade, F. (2012). Thinking like a fish: a key ingredient for development of effective fish passage facilities at river obstructions. River Research and Application

Zgrabczyński, J. (2007). Identyfikacja i ocena sprawności przepławek dla ryb w regionie wodnym Warty. Nauka Przyroda Technologie, 1(2), 35.

\section{WYBÓR OPTYMALNEGO TYPU PRZEPŁAWKI DLA RYB Z WYKORZYSTANIEM METODY REMBRANDT}

\section{ABSTRAKT}

\section{Cel pracy}

Celem pracy była próba wykorzystania metody wielokryterialnego wspomagania decyzji Rembrandt do wyboru najlepszego typu przepławki dla analizowanego stopnia wodnego w zależności od wykorzystanych priorytetów.

\section{Materiał i metody}

Budowle hydrotechniczne powodują przerwanie ciagłości morfologicznej i biologicznej cieku, dzielą go na odcinki, których granic ryby i inne organizmy wodne nie mogą przekraczać co jest szczególnie niekorzystne ponieważ przemieszczającą się one wyniku różnych potrzeb życiowych. Dlatego na stopniach wodnych buduje się przepławki dla ryb, które ułatwiają ich migrację. W pracy przeprowadzono obliczenia hydrauliczne dla trzech założonych typów przepławek dla ryb. Następnie przygotowano 
drzewo hierarchiczne zgodne z metodą Rembrandt. Drzewo to zostało rozwiązane trzykrotnie zgodnie z preferencjami inwestora, organizmów które z niego korzystają, a także bez narzucania wag drugiemu poziomowi obliczeń.

\section{WYNIKI I WNIOSKI}

Wyniki obliczeń metodą wielokryterialnego wspomagania decyzji Rembrandt wskazały że według priorytetów inwestora najlepszą przepławką była konstrukcja szczelinowa, dla organizmów wodnych kanał obiegowy, a dla obliczeń w których wagi przyjmowały równe wartości dla poszczególnych czynników poziomu II również przepławka szczelinowa.

Słowa kluczowe: przepławki dla ryb, stopień wodny, metoda Rembrandt 